\title{
PROPOSTA DE METODOLOGIA PARA AVALIAÇÃO HIDROGEOLÓGICA DO AQUÍFERO CÁRSTICO, COMPARTIMENTO DE SÃO MIGUEL

\author{
ALVAROAMORETTI LISBOA
}

\author{
DISSERTAÇÃO DE MESTRADO - Programa de Pós-Graduação em Geologia - UFPR \\ DATA DE DEFESA: 05/12/97
}

\begin{abstract}
A identificação e qualificação de uma unidade compartimental com características próprias e reprodutíveis para o todo, do ponto de vista hidrogeológico, no aqüífero cárstico, situado à norte da Região Metropolitana de Curitiba, possibilita o estabelecimento de uma política de uso sustentado e proteção ambiental do mesmo. A viabilidade de um gerenciamento e proteção adequada do aqüífero, depende de uma redefinição no modelo de planejamento urbano da Região Metropolitana, estabelecendo o meio físico como parâmetro de planejamento em substituição à bacia hidrográfica. Até o presente momento, os planos diretores para abastecimento público da cidade de Curitiba e arredores, são fundamentados na utilização de mananciais superficiais, em franco processo de degradação. Uma nova alternativa aventada é o uso do aqüifero carste, com melhor qualidade e menores custos, carecendo, no entanto, de uma metodologia adequada para o seu estudo. $O$ aqüífero cárstico apresenta uma relação direta com a existência de rochas carbonáticas com grande capacidade de dissolução, representadas pelos mármores. A massa carbonática é condicionada entre delimitantes impermeáveis representados por cristas de filitos e quartzitos, segundo direção preferencial NE-SW, e pelo enxame de diques de diabásio de idade mesozóica, com direção
\end{abstract}

preferencial NW-SE. Os diques seccionam transversalmente as cristas, originando assim uma compartimentação em unidades losangulares, com comportamento hidrogeológico similar entre si. No âmbito da unidade compartimental, diferenciam-se duas áreas, correspondendo ao afloramento das rochas carbonáticas e das rochas silicatadas, com diferentes aptidões quanto ao uso e ocupação do solo. Os maiores cuidados quanto à este aspecto, estão relacionados às zonas de recarga e descarga do aqüífero, situadas na área das rochas carbonáticas, diminuindo a restrição na área de abrangência das rochas silicatadas. O manejo hídrico combinado das águas superficiais e subterrâneas é possível no compartimento, considerando-se o caráter das limitantes impermeáveis, mediante o armazenamento da água em superfície e recarga artificial do aqüífero, promovendo a sua regularização, durante os períodos de superávit hídrico. No contexto geral da Região Metropolitana de Curitiba, o compartimento qualifica-se por aptidão natural para exploração da água subterrânea para abastecimento público, uso agrícola com cinturão verde e reflorestamento, bem como exploração mineral do calcáreo, sendo inadequado para assentamento urbano adensado. 